\title{
Safe handling and movement of cocoa germplasm for breeding
}

Book or Report Section

Accepted Version

Daymond, A. (2018) Safe handling and movement of cocoa germplasm for breeding. In: Umaharan, P. (ed.) Achieving sustainable cultivation of cocoa. Burleigh Dodds, Reading. ISBN 9781786761682 Available at http://centaur.reading.ac.uk/79464/

It is advisable to refer to the publisher's version if you intend to cite from the work. See Guidance on citing.

Publisher: Burleigh Dodds

All outputs in CentAUR are protected by Intellectual Property Rights law, including copyright law. Copyright and IPR is retained by the creators or other copyright holders. Terms and conditions for use of this material are defined in the End User Agreement. 


\section{CentAUR}

Central Archive at the University of Reading

Reading's research outputs online 


\title{
Safe handling and movement of cocoa germplasm for breeding
}

Andrew Daymond, University of Reading, UK

\begin{abstract}
Cocoa (Theobroma cacao L.) originated in South America, but is now cultivated in various parts of the tropics. Movement of cocoa germplasm is often required in breeding programmes to increase the genetic diversity pool or to test clones/progeny in the field. However, such movement brings with it the risks of spread of pests and diseases, many of which are confined to particular geographical locations. Thus, it is critical that movement of germplasm is conducted within a quarantine framework. This chapter reviews the risks associated with the movement of cocoa germplasm. It considers international governance of plant movement and discusses the International Cocoa Quarantine Centre at the University of Reading (ICQC,R) as a hub for safe handling and movement of cocoa germplasm.
\end{abstract}

Key Words: Safe movement, quarantine, breeding, cocoa germplasm

1. Introduction

2. Overview of risks associated with plant movement

3. Levels of risk

4. Risk management governance and procedures

5. Case study: International Cocoa Quarantine Centre, Reading

6. Concluding remarks

7. Where to look for further information

8. References

\section{Introduction}

Whilst the centre of diversity of cocoa (Theobroma cacao L.) is in Central and South America, figures from ICCO (2016) indicate that $84 \%$ of current cultivation takes place in West Africa and South East Asia. Since the majority of cocoa is cultivated away from its centre of diversity, movement of germplasm between countries and from the international cocoa genebanks has been integral to the expansion of production.

Cocoa farmers frequently face challenges to production in the form of low potential yields of existing cultivated varieties or losses associated with pest and disease pressures. Furthermore, abiotic stress (such as periods of drought) can influence both crop establishment and yield development of cocoa. With a changing climate, such stresses are likely to become more acute in some growing regions in the future. A route to improving on-farm yields is through breeding varieties that have a higher yield potential and a greater tolerance to pests, diseases and abiotic stresses. Access to a broad range of genetic diversity is an important prerequisite for breeding programmes (e.g. Padi et al., 2016). This is particularly important since most of the cultivated varieties in West Africa have been bred from a relatively narrow genetic base (Zhang and Motilal, 2016). Given that much of the production of cocoa is away from the centre of diversity, there is a need for movement from the global genebanks, such as those in Trinidad and Tobago (Iwaro et al., 2003) and Costa Rica (CacaoNet, 2012) to research institutes engaged in evaluation and breeding of cocoa. However, such movement brings with it the risk of transfer of pests and diseases. Therefore, it is critical that movement of germplasm is conducted within a quarantine framework. 


\section{Overview of risks associated with plant movement}

Potential losses to pests and diseases are difficult to quantify with some having a much greater impact than others. However, a global figure of a loss in excess of $30 \%$ is often quoted (Hebbar, 2007). Some pests and diseases of cocoa are found throughout cocoa-growing regions, while others have a nonuniform geographical distribution. An example of a widespread pathogen is Phytophthora palmivora (one of the causal agents of black pod disease). Pathogens confined to particular regions include frosty pod rot (causal agent: Moniliophthora roreri), which is encountered in parts of South and Central America and more recently in one Caribbean island (IPPC, 2016); cacao swollen shoot virus (CSSV) disease, which is encountered in West Africa (Ghana, Côte d'Ivoire, Togo and Nigeria; Muller, 2016) and vascular streak dieback, which is found in several countries in South East Asia (McMahon and Purwantara, 2016). A number of pests of cocoa are also confined to particular countries or regions. An example is cocoa pod borer which is an important pest in a number of countries within South East Asia, including Malaysia, Indonesia, the Philippines and Papua New Guinea (Awang and Lamin, 2014). The geographical spread of major pests and diseases is summarised in Table 1.

A notable example of the devastating effects of the introduction of a new disease into a new area is that of witches' broom disease in Brazil. Historically, in Brazil witches' broom disease was only found within the Amazon region where it is endemic (Evans, 2016). In 1989 it was first observed in the state of Bahia, where the majority of cocoa production takes place (Pereira et al., 1989). Since there was little genetic resistance amongst cultivated varieties, the introduction of the disease had a devastating impact on yields and consequently the economy and employment within the region (Pereira et al., 1996). Other examples of disease and pest movement include the spread of frosty pod rot within Central America (Phillips-Mora et al., 2006) and the spread of the cocoa pod borer within South East Asia (Yen et al., 2010). These examples serve to illustrate the dangers of new pest and disease encounters in a region or country and hence the vital need for quarantine measures.

\section{Levels of risk}

\subsection{Assessing and managing risks}

Movement of cocoa germplasm for breeding may comprise new material being imported into the country in question, typically in the form of budwood, which is then grafted onto the rootstocks at the destination. Movement may also take place within a given country as part of a breeding programme, for example, the setting up of clonal trials in a region to expose cocoa clones to given stresses or that of progeny trials at distant locations, which involves the movement of seed. Hence both international and within-country movement need to be considered regarding safe handling of cocoa germplasm for breeding.

The level of risk involved in moving plant material will depend upon a combination of the survivorship of pests and diseases that are present at the source, whether the pests and diseases present at source are also present at the destination and the form in which the plant material is transported. As a general rule, international movement of cocoa germplasm should be via an intermediate quarantine facility. When movement of material takes place from a country or region where a given pest or disease is present to one where it is not present, it should always be via an intermediate quarantine facility. For example, movement of germplasm from any Central or South American country to Africa and South East Asia or movement within South/Central America from a country where frosty pod rot (M. roreri) is present to one where it is not present.

It is important that scientists who are active in research are aware of the risks of moving pests or diseases on their person. In this respect, when travelling from one cocoa-growing region to another, 
research scientists need to employ a procedure that includes a change of footwear and clothing. Particular care needs to be taken when travelling from a region where frosty pod rot (M. roreri) is present as the spores of this disease are very resilient (Evans, 1981). Hence, it is not recommended to travel directly from such regions to cocoa-growing areas where this disease is not present.

\subsection{Risks associated with the movement of different plant materials}

\section{seed}

In terms of plant parts, movement of seed, which may be required, for example, in the setting up of progeny trials, represents one of the safer means of moving cocoa germplasm (End et al., 2014). However, since pod husks can be infected with fungi or house insect pests, movement of whole pods is not recommended. Furthermore, care should be taken to select pods that do not exhibit visual symptoms of diseases, and a treatment with fungicide should be considered before opening the pods to prevent surface contamination of seed. In areas where CSSV is present, precautions are needed to prevent transport of mealybug vectors of the disease. Campbell (2014) highlighted the fact that mealybug nymphs can feed on the cotyledons of cocoa seeds that might be damaged during podsplitting and therefore suggested dipping pods in an insecticide solution before seeds are extracted and transported. Awang and Lamin (2014) highlighted the importance of selecting pods with no signs of insect boring and recommend washing the seed in an insecticide solution.

\section{Budwood}

Movement of budwood is commonly practised for the purpose of plant breeding in order to maintain the genetic integrity of the material. As budwood may be infected with a number of viruses, international movement of budwood should only take place via an intermediate quarantine facility where virus indexing is conducted. Quarantine measures may be needed when budwood is moved within a country where viruses, such as CSSV, are present (see Case Study and Regional/WithinCountry Quarantine Measures sections).

\section{Whole plants}

Whole plants represent a high-risk route for cocoa germplasm movement due to the risk of transfer of insect pests and soil-borne organisms such as nematodes and therefore plants should not be moved internationally in soil. International movement of bare-rooted cocoa plants is not recommended, unless it takes place via an intermediate quarantine facility.

\section{In vitro movement}

Movement of plant material in vitro, for example, somatic embryos, should be in sealed containers containing sterile growth media. The material should be indexed for the presence of pathogens within a quarantine facility.

\section{Risk management governance and procedures}

\subsection{International governance of plant movement}

The International Plant Protection Convention (IPPC) was established to regulate the movement of plant material in order to reduce the spread of pests and diseases (IPPC, 2017). In particular, the convention provides a template for phytosanitary certificates. It also requires that signatories to the agreement should have a specifically assigned health authority to deal with imports and exports of plant material. Thus, any international movement of cocoa germplasm, regardless of the form in which it is moved (e.g. budwood, somatic embryos, seed), must comply with IPPC regulations. Specifically, the movement of germplasm should take place in consultation with the relevant plant health authorities in both the exporting and importing countries. This involves the plant health authority in 
the importing country providing permission in the form of an import permit for germplasm to enter the country from a stated source. The import permit will also state whether any specific tests should have taken place on the material being exported and whether any treatments are required, such as a pesticide/fungicide dip, before export. The plant health authority in the exporting country will provide a phytosanitary certificate which lists any treatments that the plant material was subjected to.

\subsection{Within-country quarantine procedures}

Within-country movement of cocoa germplasm sometimes takes places as part of a breeding programme, for example, the establishment of clonal trials at a research substation. Here, a quarantine procedure may be needed, particularly if a pest or disease is present at the source location which is not present at the destination. A notable example is the within-country movement of cocoa budwood from sources where CSSV is present. Here, a procedure should be adopted to index donor plants before budwood is transported.

\section{Case study: International Cocoa Quarantine Centre, Reading}

The International Cocoa Quarantine Centre at the University of Reading (ICQC,R), UK, is currently the main hub for international movement of cocoa germplasm (Daymond et al., 2006; Turnbull et al, 2010; see Fig. 1). It has been in operation since 1985, when it acquired a number of cocoa accessions from the Royal Botanic Gardens at Kew, London, which had previously had a responsibility for intermediate quarantine of cocoa. It is currently funded by the Cocoa Research Association and the United States Department of Agriculture. The location of ICQC, $R$ in a temperate country in which cocoa is not cultivated is significant in that there is no risk of specific pests and diseases of cocoa entering the facility. Indeed, it is a requirement of some cocoa-producing countries that when they import material from abroad it should have undergone quarantine in a non-producing country. It is an intermediate quarantine facility in that further post-entry quarantine procedures may take place after the material has been exported. The facilities comprise $1000 \mathrm{~m}^{2}$ of compartmentalised greenhouses that are heated to provide tropical conditions. Plants are grown in an inert medium and are regularly watered via an automated system with a nutrient solution. This set-up minimises the chance of establishment of invertebrate pests in the medium and also eases plant management. The greenhouses are insectproofed and access to them is strictly controlled to prevent entry of pests on the clothes or footware of individuals. Specifically, a standard operational procedure is maintained which prohibits the entry of anybody that has recently been in the field.

As of 2017, the International Cocoa Quarantine Centre contains 400 cocoa accessions, 369 of which are available for international export. These accessions have been received from the two international cocoa genebanks in Trinidad and Tobago and Costa Rica as well as from a number of national genebanks. Material that has particularly desirable traits for breeders such as high yield potential, large bean size and a level of resistance/tolerance to economically important pests and diseases is brought into quarantine.

The procedures in place at the ICQC, R for receipt and quarantine of cocoa germplasm, which serve as an exemplar of a quarantine procedure, are summarised as follows:-

i. At the source (donor country providing germplasm to ICQC,R), budwood is selected from stock trees that show no visible signs of pests or diseases. After cutting the budwood it is then dipped in a mixture of pesticide and fungicide.

ii. The material is inspected by the relevant authority and a phytosanitary certificate is provided. 
iii. On receipt at ICQC, $R$, the budwood is inspected in the laboratory under a microscope for any signs of the presence of insects, eggs or fungal spores. In the event that any insects, eggs or fungi should be observed, the material in question is autoclaved and destroyed.

iv. In the case of cocoa budwood that is received from a country in which vascular streak dieback is present, samples of budwood are dissected to examine for the presence of characteristic streaking symptoms.

v. Imported material is then grafted onto rootstocks in a greenhouse compartment that is maintained specifically to establish new material from abroad. After grafting, the budwood along with the packaging material is autoclaved.

vi. The grafted plants are initially kept in insect-proof cages and are carefully observed after grafting for signs of the presence of any insects that may have survived the insecticide treatment.

vii. Received material is subjected to virus indexing using two methodologies: a laboratorybased polymerase chain reaction (PCR) technique and in situ screening. Leaf samples are taken at an early stage after the establishment of the imported grafted plant from an actively growing flush. These are then tested in the laboratory using a suite of PCR probes. Since PCR-based methods do not currently detect all viruses of cocoa, a visual indexing test is also utilised (Thresh, 1960), which involves the following steps:

a. Budwood is taken from an accession that has recently been established from abroad ('mother plant') and buds are grafted onto seedlings of West African Amelonado, a variety that shows clear symptoms in the flush leaves when it is infected with viruses such as CSSV. A minimum of three such indicator plants are established.

b. Once the buds have formed a union with the seedlings, the mother plant and indicator plants are moved to a greenhouse compartment specifically for the purpose of virus indexing. Here, indicator plants are inspected on a weekly basis for the characteristic leaf symptoms and stem swellings.

c. In the event that virus symptoms are observed, the mother plant, along with the test plants, is destroyed by autoclaving or incineration.

viii. After the two-year quarantine period has been completed for a given accession and if it has a clean quarantine record, the mother plant is moved to the greenhouse compartment that houses the post-quarantine collection and the test plants are destroyed.

The inventory of cocoa accessions ('clones') held at the ICQC, $R$ is maintained within an online database that can be accessed at www.icgd.reading.ac.uk/icqc/.

In response to requests from institutes engaged in cocoa breeding and research, plant material in the form of budwood is periodically exported from the ICQC,R post-quarantine collection. To facilitate this, the recipient institute provides an import permit that has been issued by the relevant authority (Ministry of Agriculture or Plant Health body), along with the requested clone list. On the designated day of export, budwood is cut from actively growing branches and the leaves are removed. The material is then inspected by an officer of the UK Animal and Plant Health Authority who provides the phytosanitary certificate. The budwood is treated by dipping it in a mixture of pesticide and fungicide if this is a stated requirement of the import permit. It is then wrapped in damp paper towel and placed in a sealed polythene bag to maintain viability after it has been transported. A material transfer agreement is also issued which ensures that the germplasm remains in the public domain.

A series of quality control measures are in place within the ICQC, $R$ facilities. These include twice-yearly inspections by expert consultants in pathology, virology and entomology, who report to a Quarantine 
Advisory Board. The board also reviews the activities of the ICQC,R and considers any necessary amendments to the modus operandi of the facility. An annual inspection of the facilities by an officer of the UK Animal and Plant Health authority is also conducted. As of 2017, germplasm has been provided from the International Cocoa Quarantine Centre to institutes in over thirty different countries.

\section{Concluding remarks}

Breeding new varieties of cocoa is a major component of improving on-farm yields to meet expected future demand for cocoa products. Quarantine procedures and facilities provide the mechanism to enable researchers have access to the genetic diversity required for such breeding programmes. Continued research is needed to increase the range of tools available to quarantine centres, such as laboratory screens for a broader range of diseases. Furthermore, in an increasingly globalised world, there is an ongoing requirement to raise awareness of the risks associated with cocoa germplasm movement and the need for quarantine measures (both intermediate quarantine and within-country measures) to negate these risks.

\section{Where to look for further information}

The Technical Guidelines for the Safe Movement of Cacao Germplasm are published online at http://www.cacaonet.org/and are currently available in English, French and Spanish. The document provides general guidance for the safe movement of cocoa germplasm and also specific information on different pests and diseases, particular risks associated with them and quarantine measures required. Each section on a particular pest or disease is authored by an expert in that area. The guidelines are periodically reviewed and updated to take into account new information, for example, on the spread of a particular disease or new disease detection methods.

Information on the International Cocoa Quarantine Centre may be found at www.icgd.reading.ac.uk/icqc/. The website includes a continually updated list of cocoa germplasm and a link to the International Cocoa Germplasm Database (ICGD), which provides information on specific accessions as well as their genetic fingerprint.

Further information about the International Plant Protection Convention can be found at: https://www.ippc.int/en/.

\section{References}

1. Awang, A. and Lamin, K. 2014. Cocoa pod borer. In: Technical Guidelines for the Safe Movement of Cacao Germplasm. Revised from the FAO/IPGRI Technical Guidelines No. 20 (Second update, August 2014) (M. J. End, A. J. Daymond and P. Hadley (Eds)). Global Cacao Genetic Resources Network (CacaoNet), Bioversity International, Montpellier, pp. 66-70.

2. CacaoNet. 2012. A global strategy for the conservation and use of cacao genetic resources, as the foundation for a sustainable cocoa economy (B Laliberté complier). Bioversity International, Montpellier, France.

3. Campbell, C. A. M. 2014. Other insects. In: Technical Guidelines for the Safe Movement of Cacao Germplasm. Revised from the FAO/IPGRI Technical Guidelines No. 20 (Second update, August 2014) (M. J. End, A. J., Daymond and P. Hadley (Eds)). Global Cacao Genetic Resources Network (CacaoNet), Bioversity International, Montpellier, pp. 74-9. 
4. Daymond, A. J., Fenn, M. G. E., Binns, H. and Hadley, P. 2006. The university of reading intermediate cocoa quarantine facility. In: Proceedings of the Malaysian International Cocoa Conference, Kuala Lumpur, Malaysia. July 2005, pp. 362-6.

5. End, M. J., Daymond, A. J. and Hadley, P. (Eds). 2014. Technical Guidelines for the Safe Movement of Cacao Germplasm. Revised from the FAO/IPGRI Technical Guidelines No. 20 (Second update, August 2014). Global Cacao Genetic Resources Network (CacaoNet), Bioversity International, Montpellier.

6. Evans, H. C. 1981. Pod rot of cacao caused by Moniliophthora (Monilia) roreri. Phytopathological Papers, 24, 44.

7. Evans, H. C. 2016. Witches' broom disease (Moniliophthora perniciosa): History and biology. In: Cacao Diseases: A History of Old Enemies and New Encounters (B. A. Bailey and L. W. Meinhardt (Eds)). Springer International Publishing, pp. 137-78. New York Dordrecht London.

8. Hebbar, P. K. 2007. Cacao diseases: A global perspective from an industry point of view. Phytopathology, 97, 1658-63. (doi:10.1094/PHYTO-97-12-1658)

9. ICCO. 2016. Quarterly Bulletin of Cocoa Statistics, Vol. XLII, No. 3, Cocoa Year 2015/16. http://www.icco.org/about-us/international-cocoa-agreements/cat_view/30-relateddocuments/46-statistics-production.html. Accessed November 2016.

10. IPPC. 2016. Detection of Frosty Pod Rot in Jamaica. Pest Report, September 2016.

11. IPPC. 2017. https://www.ippc.int/en/structure/. Accessed June 2017.

12. Iwaro, A. D., Bekele, F. L. and Butler, D. R. 2003. Evaluation and utilisation of cacao (Theobroma cacao L.) genotypes at the International Cocoa Genebank, Trinidad. Euphytica, 130, 207-21. (doi:10.1023/A:1022855131534)

13. McMahon, P. and Purwantara, A. 2016. Vascular streak dieback (Ceratobasidium theobromae): History and biology. In: Cacao Diseases: A History of Old Enemies and New Encounters (B. A. Bailey and L. W. Meinhardt (Eds)). Springer International Publishing, pp. 30735. New York Dordrecht London

14. Muller, E. 2016. Cacao swollen shoot virus (CSSV): History, biology and genome. In: Cacao Diseases: A History of Old Enemies and New Encounters (B. A. Bailey and L. W. Meinhardt (Eds)). Springer International Publishing, pp. 337-58.

15. Padi, F. W., Ofori, A. and Akpertey, A. 2016. Genetic base-broadening of cacao for precocity and cropping Plant Genetic Resources. https://doi.org/10.1017/\$1479262116000277

16. Pereira, J. L., Ram, A., Figueredo, J. M. and Almeida, L. C. C. 1989. Primeira ocorrência de vassoura-de-bruxa na principal região produtora de cacao de Brasil. Agrotrópica, 1, 79-81.

17. Pereira, J. L., Almeida, L. C. C. and Santos, S. M. 1996. Witches' broom disease of cocoa in Bahia: Attempts at eradication and containment. Crop Protection, 15, 743-52. (doi:10.1016/S0261-2194(96)00049-X) 
18. Phillips-Mora, W., Coutiño, A., Ortiz, C. F., Lopez, A. P., Hernández, J. and Aime, M. C. 2006. First report of Moniliophthora roreri causing frosty pod rot (Moniliasis disease) of cocoa in Mexico. Plant Pathology, 55, 584. (doi:10.1111/j.1365-3059.2006.01418.x)

19. Thresh, J. M. 1960. Quarantine arrangements for intercepting cocoa material infected with West African viruses. FAO Plant Protection Bulletin, 8, pp. 89-92.

20. Turnbull, C. J., Daymond, A. J., Lake, H., Main, N. E., Radha, B., Cryer, N. C, End, M. J. and Hadley, P. 2010. The role of the international cocoa germplasm database and the international cocoa quarantine centre in information management and distribution of cocoa genetic resources. In: Proceeding of the 16th International Cocoa Research Conference. Bali, November 2009, pp. 33-9.

21. Yen, D. L., Water, E. K. and Hamilton, A. J. 2010. Cocoa pod borer (Conopomorpha cramerella Snellen) in Papua New Guinea: Biosecurity models for New Ireland and the Autonomous Region of Bougainville. Risk Analysis, 30, 293- 309. (doi:10.1111/j.15396924.2009.01297.x)

22. Zhang, D. and Motilal, L. (2016). Origin, dispersal, and current global distribution of cacao genetic diversity. In: Cacao Diseases: A History of Old Enemies and New Encounters (B. A. Bailey and L. W. Meinhardt (Eds)). Springer International Publishing, pp. 3-31. New York Dordrecht London

Click here to enter text.Figure 1. The International Cocoa Quarantine Centre at the University of Reading, UK.

Click here to enter text.Table 1. Distribution of the main pests and diseases of cocoa by country (adapted from End et al. (2014); information is based on published information at the time of writing). Species of Phytophthora, the causal agent of black pod are widespread and so are not listed, with the exception of Phytophthora megakarya, which is a particular virulent strain. Rosellina root rot and mirid species are also widespread

\begin{tabular}{|l|l|l|}
\hline Geographical region & Country & Pest/Disease risk \\
\hline $\begin{array}{l}\text { Central America and } \\
\text { Caribbean }\end{array}$ & Belize & Moniliophthora pod rot \\
\hline & Costa Rica & $\begin{array}{l}\text { Moniliophthora pod rot } \\
\text { Ceratocystis wilt }\end{array}$ \\
\hline & El Salvador & Moniliophthora pod rot \\
\hline & Grenada & Witches' broom disease \\
\hline & Jamaica & Moniliophthora pod rot \\
\hline & Mexico & Moniliophthora pod rot \\
\hline & Nicaragua & Moniliophthora pod rot \\
\hline
\end{tabular}




\begin{tabular}{|c|c|c|}
\hline & Panama & $\begin{array}{l}\text { Moniliophthora pod rot } \\
\text { Witches' broom disease }\end{array}$ \\
\hline & St Vincent & Witches' broom disease \\
\hline \multirow[t]{11}{*}{ South America } & Bolivia & $\begin{array}{l}\text { Witches' broom disease } \\
\text { Moniliophthora pod rot }\end{array}$ \\
\hline & Brazil & $\begin{array}{l}\text { Ceratocystis wilt } \\
\text { Verticillium wilt of cacao } \\
\text { Witches' broom disease }\end{array}$ \\
\hline & Colombia & $\begin{array}{l}\text { Ceratocystis wilt } \\
\text { Moniliophthora pod rot } \\
\text { Verticillium wilt of cacao } \\
\text { Witches' broom disease }\end{array}$ \\
\hline & Ecuador & $\begin{array}{l}\text { Ceratocystis wilt } \\
\text { Moniliophthora pod rot } \\
\text { Witches' broom disease }\end{array}$ \\
\hline & French Guiana & Witches' broom disease \\
\hline & Guyana & Witches' broom disease \\
\hline & Honduras & Moniliophthora pod rot \\
\hline & Peru & $\begin{array}{l}\text { Witches' broom disease } \\
\text { Moniliophthora pod rot }\end{array}$ \\
\hline & Suriname & Witches' broom disease \\
\hline & Trinidad and Tobago & $\begin{array}{l}\text { Witches' broom disease } \\
\text { Ceratocystis wilt }\end{array}$ \\
\hline & Venezuela & $\begin{array}{l}\text { Witches' broom disease } \\
\text { Moniliophthora pod rot } \\
\text { Ceratocystis wilt }\end{array}$ \\
\hline \multirow[t]{5}{*}{ Africa } & Benin & Cacao swollen shoot virus (CSSV) \\
\hline & Bioko (Fernando Po) & Phytophthora megakarya \\
\hline & Cameroon & Phytophthora megakarya \\
\hline & Côte d'Ivoire & $\begin{array}{l}\text { Cacao swollen shoot virus } \\
\text { Phytophthora megakarya }\end{array}$ \\
\hline & Ghana & $\begin{array}{l}\text { Cacao necrosis virus (CNV) } \\
\text { Cacao swollen shoot virus (CSSV) } \\
\text { Phytophthora megakarya }\end{array}$ \\
\hline
\end{tabular}




\begin{tabular}{|c|c|c|}
\hline & & \\
\hline & Liberia & Cacao swollen shoot virus (CSSV) \\
\hline & Nigeria & $\begin{array}{l}\text { Cacao necrosis virus (CNV) } \\
\text { Cacao swollen shoot virus (CSSV) } \\
\text { Phytophthora megakarya }\end{array}$ \\
\hline & Sierra Leone & $\begin{array}{l}\text { Cacao swollen shoot virus (CSSV) } \\
\text { Cacao yellow mosaic virus }\end{array}$ \\
\hline & Sri Lanka & Virus (unknown type reported) \\
\hline & Togo & $\begin{array}{l}\text { Cacao swollen shoot virus (CSSV) } \\
\text { Phytophthora megakarya }\end{array}$ \\
\hline & Uganda & Verticillium root rot \\
\hline \multirow[t]{7}{*}{ South and South East Asia } & India & Vascular streak dieback \\
\hline & Indonesia & $\begin{array}{l}\text { Cocoa pod borer } \\
\text { Vascular streak dieback }\end{array}$ \\
\hline & Malaysia & $\begin{array}{l}\text { Cocoa pod borer } \\
\text { Vascular streak dieback }\end{array}$ \\
\hline & Papua New Guinea & $\begin{array}{l}\text { Cocoa pod borer } \\
\text { Vascular streak dieback }\end{array}$ \\
\hline & Philippines & $\begin{array}{l}\text { Vascular streak dieback } \\
\text { Cocoa pod borer }\end{array}$ \\
\hline & Thailand & Vascular streak dieback \\
\hline & Vietnam & Vascular streak dieback \\
\hline
\end{tabular}

